\title{
ADA wt Allele
}

National Cancer Institute

\section{Source}

National Cancer Institute. ADA wt Allele. NCI Thesaurus. Code C49349.

Human ADA wild-type allele is located within 20q12-q13.11 and is approximately $32 \mathrm{~kb}$ in length. This allele, which encodes adenosine deaminase protein, is involved in the hydrolysis of adenosine to inosine. Certain allelic variants of the ADA gene are associated with adenosine deaminase deficiency which, in some cases, causes autosomal recessive severe combined immunodeficiency. 